\title{
Developing of Indonesian Learning Model Based on SCREAM for Slow Learners
}

\author{
Nur Hasyim ${ }^{1}$, Ade Sukma ${ }^{2}$, Sri Wahyono ${ }^{3}$ \\ Departement of English Translation, Politeknik Negeri Jakarta, Indonesia
}

\begin{abstract}
This research investigated developing of Indonesian learning model based on SCREAM for slow learners. The SCREAM is (i) Structure, (ii) Clarity, (iii) Redundancy, (iv) Enthusiasme, (v) Appropriate Pace, (vi) and Maximized Engagement, by Mangunsong (2011). While the research question is "how is the learning model based on SCREAM for Slow Learners?" The research implemented by development researh, by focusing group discussion with expert of education, psychology, and linguistics, and using qualitative data analysis as its data analysis method. The result is (i) learning model must be based on the structure of language, (ii)the explanation of materails mus be described clearly, (iii) the lesson repetation given with different method, (iv) class atmosphere should be enthusiastic, (v) the oral lesson must be given in compatible rythm, and (vi) the lesson based on right standard competences. This model is experimented to Politeknik Negeri Jakarta slow Learners in 2012/2013 year acedemic students. The result is students more enthuiastic to learn of Indonesian.
\end{abstract}

Keywords: slow learners, Indonesian, learning model

\section{Introduction}

The Presence of Peraturan Menteri Pendidikan Nasional Republik Indonesia No. 70, Tahun 2009tentang Pendidikan Inklusif bagi Peserta Didik yang Memiliki Kelainan dan Memiliki Potensi Kecerdasan dan/atau Bakat Istimewagive opportunity for Indonesia citizens who destined as slow learner study because with that rules they can follow education in university. In the year 2003, PoliteknikNegeri Jakarta, has managed diploma 3 for the citizens of the special needed one of the participants are citizens as slow learner. Slow learners are those who have intelligence intellectual 66-79 (appropriate WISC-R scale), with the main characteristic are slow in processing information: changing certain object with other object, understand more than one command, need more time for understanding appropriate (Muppudathi, 2014). One of the consequence from managing the oppurtinity slow learner students are need preparing education management with the adequate language learning model in order to students can be competent citizens and independent as citizens in general.

As regards with the availability the language lerning model, in particular Indonesian learning model that still limited. This marked based on the results of the early study this research, it is just found only one Indonesian learning model for slow learner students, that is Hasyim research (2015) with the headline research "Pengembangan Model Pembelajaran Bahasa Indonesia berbasis penguatan rasionalitas bagi mahasiswa lamban belajar." However, found some research that be related to this research, namely (i) "Role of Teachers on Helping Slow Learners to Bring Out Their Hidden Skill" (Muppudathi, 2014), (ii) "Penangan insan lamban belajar dan pembelajaran bahasa Indonesia lamban belajar pada tingkat sekolah dasar" (Yustika dkk., 2013), dan (ii) "Pengembangan bahasa Inggris-tulis" (Ghita dan Krishnan, 2014) that will be explained in the Theory section.

\section{Literature Study}

Developing of Indonesian learning model in this research refer to SCREAM theory presented by Simangunsong (2009). SCREAM theory is learning theory that can be used as manual basis in performing learning at various discipline knowledge, in particular used for them with slow learner capability or comprehension condition toward specific limited knowledge. SCREAM theory include six aspects: (i) Structure, (ii) Clarity, (iii) Redundancy, (iv) Enthusiasme, (v) Appropriate Pace, (vi) andMaximized Engagement. Structurethat learning is perform by giving structure or pattern. Clarity is that learning need to delivered clearly. Redundancy is that learning is carried out by providing repetition. Enthusiasme is that learning needs to be done that participants students excited followed him. AppropriatePace is that teachers and school lecturers need to gave the proper in order to facilitate the understanding of participants students. MaximizedEngagement is that teachers have to worry about efforts attainment of results learning maximum. With reference to the theory will be built model learning the indonesian language for slow learner student learning.

As delivered in introducing that be found some research related to this research focus. That's research can be explain as the following. Hasyim (2015) has done research about Pengembangan Model Pembelajaran Bahasa Indonesia bagi Mahasiswa Lamban Belajar Berbasis Rasionalitas. That research conclude that learning Indonesian language for slow learner students need done with developing efforts that can developing and increase reasonable power, such as can be done with learning according the steps and By doing it interesting that attract as an effort to optimize intelligence intellectual.

Muppudathi (2014) in his article entitled "Role of Teachers on Helping Slow Learners to Bring Out Their Hidden Skill" delivered that need applicative and strategic in manage slow learner to achieve optimal result, such as need synergy parents and teachers. He thought, role that teachers can do is (i) building up confidence, (ii) pay equal attention in the 


\section{International Journal of Science and Research (IJSR) \\ ISSN (Online): 2319-7064}

Index Copernicus Value (2013): 6.14 | Impact Factor (2015): 6.391

class room, (iii) arrangement for special resources, (iv) repetition, dan (v) maintaining friendly relationship.

Yustika dkk. (2013) said that knowing vocal capability slow learner children can be increase $80 \%$ by using puzzle model, which is one of vocal, then students were asked guessing vocal that blank.

Ghita dan Krishnan (2014) in their article called "Developing Written English to Multimedia for Slow Learner" said that the use of multimedia can increase writing ability (English) students; teachers also need too suggesting in order to students read many books, journal, and listening English speech from radio, television, and native speaker.

\section{Problem Definition}

This research issues is Indonesian learning model for slow learner students still not available so that need developed Indonesian learning model based SCREAM so that slow learner can be competent citizens and independent like citizens in general.

\section{Methodology}

The research implemented by development researh, by focusing group discussion with expert of education, psychology, and linguistics, and using qualitative data analysis as its data analysis method.

\section{Result and Discussion}

\subsection{Result}

The research result is Indonesian learning model for slow learner student based on SCREAM, as the following. The purpose of Indonesia learning outcome is students can write and speak used Indonesia that good and right. The matter required to support the purpose of learning, at least, is (i) language variation, (ii) effective sentence, (iii) paragraph, (iv) text type/genre.As for, the significant role from that material is "sentence"material. In order to deliver some of material can used as learning basis is SCREAM theory.

\section{A. First is Structure}

In order teaching Indonesia, lecturer need catch structure/pattern from the material that was delivered. The pattern from variation material is that Indonesia language is not just one, but have many variation; Indonesia language bahasa Indonesia should be used in accordance situation and needed so the user cannot used Indonesia language as his own. User must know the situation is official or casual. If the situation is casual, user can used Bahasa that not standart. If the situation is official, user must used the standartBahasa.Regarding the form and meaning of accretion, lecturer can give an explanation, for example that the word working with one syllable if get prefix me-n, me-N will be menge-, for example basic word pel will be mengepel, basic word tik will be mengetik. Regarding the sentence, lecturer can tell various pattern/sentence structure, namely S P O pattern, for example I read a book. Then students asked to sentence. Similarly, paraghraph material and text type, lecturer need find the pattern from the make a different given materials. The principle of the delivery of this structure well done to make the material more easily understood by the learners.

\section{B. Second is Clarity}

Slow learner students in general have a low relative concentration. Because of that, lecturer need explain the given material by oral or writing clearly. Is not advised lecturer writing is too small. Lecturer in giving lecture advise use verbal and non-verbal languange such as hand gesture, mimic, picture, sound. Lecture need use multimodalitas: verbal or non-verbal. At least, lecturer need write or pronounce the material and linguistic unit clearly so the linguistic unit can understandable well.

\section{Third is doing Repetition}

For make sure the material can understandable well by the students, repetition needs to be done. However, repetition need to be done in how or different method, for example giving explanation lectures method, lecturer need repeting in a way acting and singing.

\section{Forth is make They be Enthusiasme}

Teaching Indonesian language in interesting way is needed. In order to explaining a certain material, lecturer need use varied method and learning media. We can asked the student to visiting class or certain place that have connection with the material too. Need efforts so they can have fun or smiling when attending the Indonesian learning. Give them new experiencess about Indonesian.

\section{E. Fifth is Appropriate Pace}

Lecturer need have done appropriate pace especially when teaching things that related with oral: listening and reading/pronouncing. Lecturer need to understand that students are slow learner study who generally they not fully understand vocal and consonant Indonesia language. So that, lecturer must pronounce speech and linguistic unit with tempo and a proper rhythm.

\section{F. Sixth isMaximized Engagement}

Result learning is the main learning target. Because of that, while continue to make improvement learning, lecturer must done evaluation achievements and learning results: achieved, was enough achieve, less achieve, or not achieved. That need have done in order to maximize learning result.Do not get lecturer too exciting with the interesting learning or repetation, but learning result actually not achieved. It is not expected.

Indonesian learning model based on SCREAM have writer applying. The results is slow learner students can keep up Indonesian learning well done. However, increasing Indonesian language skill will not be known for sure. Need more research in order to know the effectiveness of model.

SCREAM implementation model is that learning advised with (i) student centered approach, (ii) inductive strategic, start with specific things then general things so can easier to understand, (iii) variation of learning method, such as speech, discussion, acting, and demonstration, (iv) leisure learning technic, and (v) learning tactic with humor but firmly.

\section{Volume 5 Issue 6, June 2016 www.ijsr.net}




\section{International Journal of Science and Research (IJSR) \\ ISSN (Online): 2319-7064}

Index Copernicus Value (2013): 6.14 | Impact Factor (2015): 6.391

\subsection{Discussion}

Teaching Indonesian for slow learner students it's not an easy task. The main issues is that they in generally slow in understanding things, includes understanding Indonesian. Because of that, learning step by step need to be done as like Hasyim suggesting (2015) that learning Indonesian for slow learner students need to be done in stages to be able to develop and improve the logical power, such as with doing interesting learning as efforts to optimize intelligence.

The application of Indonesian learning model based on SCREAM advised to optimize synergy between lecturer and parents as efforts to knowing the potential and the limitations of the students. With known the potential and limitation, lecturer will be easier to do the lecturing. This idea suitably with Muppudathi (2014) opinion.He said need strategic to manage slow learner students to get maximal result, such as meed synergy between lecturer and student parents. He said, lecture role is (i) building up confidence, (ii) pay equal attention in the class room, (iii) arrangement for special resources, (iv) repetition, dan (v) maintaining friendly relationship.

The application of Indonesian learning based on SCREAM is also recommended based on multimedia. Always need realizing that slow learner students is slow in get the information so that they must stimulated with various instrument and media learning. Learning basis multimedia is very recommended. This is in accordance Ghita dan Krishnan (2014) opinions. They said that using multimedia is able increasing writing ability (English) students.

\section{Conclusion and Advice}

Indonesian learning model based on SCREAM give an offer at Indonesian learning that based on learning system that deliver clearly, innovative, and based on learning performance. This learning model more oriented at learning basis student guidance. Need have done more research about trial model and implementation of the scope implementation greater.

\section{References}

[1] Hasyim, Nur (2015), "Pengembangan Model Pembelajaran Bahasa Indonesia berbasis penguatan rasionalitas bagi mahasiswa lamban belajar", Laporan Penelitian, 2015.

[2] Mangunsong, Frieda, (2011), Psikologi dan Pendidikan Anak Berkebutuhan Khusus. UI Depok: Lembaga Pengembangan Sarana Pengukuran dan Pendidikan Psikologi.

[3] Sugiyono [2006], Metode Penelitian Pendidikan: Pendekatan Kuantitatif, Kualitatif, dan R\&D. Bandung: Alfabeta.

[4] Muppudathi (2014) "Role of Teachers on Helping Slow Learners to Bring Out Their Hidden Skill", in International Journal of Scientific Researc, Vol. 3, Isuue 3, March.

[5] Yustika, Ririn dkk. (2013), "Meningkatkan Kemampuan Mengenal Mengenal Huruf Vokal melalui Media Puzzle bagi Anak Slow Learner”. Dalam E-Jupekhu, Vol. 2, No. 3, September 2013.

[6] Gheeta, R dan Krishnan, Javaneetha (2012), "Developing Written English through Multimedia for Slow Learnersan Experiment at Engineering College Level"Pengembangan bahasa Inggris-tulis", in Journal of Education and Practice, Vol 3, No. 4. 